\title{
Automation in high throughput/content screening for cancer stem cell drug discovery
}

\author{
Eleftherios Sachlos \\ Department of Mechanical Engineering \\ Lassonde School of Engineering, York University
}

Mounting evidence suggests that cancer development is due to a rare population of cancer stem cells (CSC) uniquely able to initiate and sustain the disease (Al-Hajj et al., 2003; Bonnet and Dick, 1997; Lapidot et al., 1994; Li and Ren, 2008; Singh et al., 2003; Smalley and Ashworth, 2003). Conventional chemotherapeutics which inhibit cell proliferation are however ineffective against quiescent CSCs capable of re-initiating the disease (Bao et al., 2006; Dean et al., 2005; Diehn et al., 2009; Diehn and Clarke, 2006; Eyler and Rich, 2008; Li et al., 2008; Woodward et al., 2007). Instead, the indiscriminate cytotoxicity of these drugs often affects normal stem cells and progenitor populations, leading to dosage restrictions and necessitating supportive treatment (Smith et al., 2006). This traditional therapy has defined current patient survival rates, but these rates remain largely unchanged during the past 3 decades (Estey and Dohner, 2006; Visvader and Lindeman, 2008) implying that novel approaches are required to fight cancer. Recently, agents that selectively induce CSC apoptosis have been identified (Gupta et al., 2009) but their impact on normal stem cells has yet to be validated.

Stem cells, whether normal or CSC, are defined by an equilibrium between 1) self-renewal and 2) differentiation. In the case of CSCs, this equilibrium shifts towards enhanced self-renewal and limited differentiation capacity. A deviation in equilibrium however leads to eventual stem cell exhaustion (Duncan et al., 2005). One approach to eradicate CSCs is to tilt the equilibrium in favour of terminal differentiation in an effort to exhaust the CSC population. Eliminating cancer by inducing differentiation was first proposed in the 1970s (Fibach et al., 1973; Friend et al., 1971; 
Sachs, 1978a; Sachs, 1978b). This led to the identification of all-trans-retinoic acid (ATRA) (Breitman et al., 1981; Breitman et al., 1980) and then arsenic trioxide (ATO) (Niu et al., 1999; Raffoux et al., 2003) as differentiation-inducing agents for the treatment of acute promyelocytic leukemia (APL), an acute myeloid leukemia (AML) subtype. If left untreateted, APL causes death within weeks. ATRA/ATO treatment of APL currently demonstrates remission rates in excess of 93\% with 5-year overall patient survival rates approaching 100\% (Sanz, 2006; Sanz et al., 2009; Wang and Chen, 2008) and exemplifies how differentiation therapy can be used to transformed a fatal, non-resectable, cancer to one that is essentially curable.

Cancer differentiation therapy has not however been translated to the treatment of other cancer types, let alone other AML subtypes (Burnett et al., 2010; Estey et al., 1999). This failure is, in part, due to the absence of robust in vitro assays which can interrogate CSC differentiation.

To address these issues, an overview of the application of automation for cancer stem cell screening will be presented. 


\section{REFERENCES}

Al-Hajj, M., Wicha, M. S., Benito-Hernandez, A., Morrison, S. J., and Clarke, M. F. (2003). Prospective identification of tumorigenic breast cancer cells. Proc Natl Acad Sci U S A 100, 3983-3988.

Bao, S., Wu, Q., McLendon, R. E., Hao, Y., Shi, Q., Hjelmeland, A. B., Dewhirst, M. W., Bigner, D. D., and Rich, J. N. (2006). Glioma stem cells promote radioresistance by preferential activation of the DNA damage response. Nature $444,756-760$.

Bonnet, D., and Dick, J. E. (1997). Human acute myeloid leukemia is organized as a hierarchy that originates from a primitive hematopoietic cell. Nat Med 3, 730-737.

Breitman, T. R., Collins, S. J., and Keene, B. R. (1981). Terminal differentiation of human promyelocytic leukemic cells in primary culture in response to retinoic acid. Blood 57, 1000-1004.

Breitman, T. R., Selonick, S. E., and Collins, S. J. (1980). Induction of differentiation of the human promyelocytic leukemia cell line (HL-60) by retinoic acid. Proc Natl Acad Sci U S A 77, 2936-2940.

Burnett, A. K., Hills, R. K., Green, C., Jenkinson, S., Koo, K., Patel, Y., Guy, C., Gilkes, A., Milligan, D. W., Goldstone, A. H., et al. (2010). The impact on outcome of the addition of all-trans retinoic acid to intensive chemotherapy in younger patients with nonacute promyelocytic acute myeloid leukemia: overall results and results in genotypic subgroups defined by mutations in NPM1, FLT3, and CEBPA. Blood 115, 948-956.

Dean, M., Fojo, T., and Bates, S. (2005). Tumour stem cells and drug resistance. Nat Rev Cancer 5, 275284.

Diehn, M., Cho, R. W., Lobo, N. A., Kalisky, T., Dorie, M. J., Kulp, A. N., Qian, D., Lam, J. S., Ailles, L. E., Wong, M., et al. (2009). Association of reactive oxygen species levels and radioresistance in cancer stem cells. Nature 458, 780-783.

Diehn, M., and Clarke, M. F. (2006). Cancer stem cells and radiotherapy: new insights into tumor radioresistance. J Natl Cancer Inst 98, 1755-1757.

Duncan, A. W., Rattis, F. M., DiMascio, L. N., Congdon, K. L., Pazianos, G., Zhao, C., Yoon, K., Cook, J. M., Willert, K., Gaiano, N., and Reya, T. (2005). Integration of Notch and Wnt signaling in hematopoietic stem cell maintenance. Nat Immunol 6, 314-322.

Estey, E., and Dohner, H. (2006). Acute myeloid leukaemia. Lancet 368, 1894-1907.

Estey, E. H., Thall, P. F., Pierce, S., Cortes, J., Beran, M., Kantarjian, H., Keating, M. J., Andreeff, M., and Freireich, E. (1999). Randomized phase II study of fludarabine + cytosine arabinoside + idarubicin +/- alltrans retinoic acid +/- granulocyte colony-stimulating factor in poor prognosis newly diagnosed acute myeloid leukemia and myelodysplastic syndrome. Blood 93, 2478-2484.

Eyler, C. E., and Rich, J. N. (2008). Survival of the fittest: cancer stem cells in therapeutic resistance and angiogenesis. J Clin Oncol 26, 2839-2845.

Fibach, E., Hayashi, M., and Sachs, L. (1973). Control of normal differentiation of myeloid leukemic cells to macrophages and granulocytes. Proc Natl Acad Sci U S A 70, 343-346.

Friend, C., Scher, W., Holland, J. G., and Sato, T. (1971). Hemoglobin synthesis in murine virus-induced leukemic cells in vitro: stimulation of erythroid differentiation by dimethyl sulfoxide. Proc Natl Acad Sci U S A $68,378-382$. 
Gupta, P. B., Onder, T. T., Jiang, G., Tao, K., Kuperwasser, C., Weinberg, R. A., and Lander, E. S. (2009). Identification of selective inhibitors of cancer stem cells by high-throughput screening. Cell 138, 645-659.

Lapidot, T., Sirard, C., Vormoor, J., Murdoch, B., Hoang, T., Caceres-Cortes, J., Minden, M., Paterson, B., Caligiuri, M. A., and Dick, J. E. (1994). A cell initiating human acute myeloid leukaemia after transplantation into SCID mice. Nature 367, 645-648.

Li, X., Lewis, M. T., Huang, J., Gutierrez, C., Osborne, C. K., Wu, M. F., Hilsenbeck, S. G., Pavlick, A., Zhang, X., Chamness, G. C., et al. (2008). Intrinsic resistance of tumorigenic breast cancer cells to chemotherapy. J Natl Cancer Inst 100, 672-679.

$\mathrm{Li}, \mathrm{X}$, and Ren, J. (2008). [Isolation of CD44+/CD24 -/low and side population cells from MDA-MB-453 cells and the analysis of their activation of Wnt and Notch pathway]. Beijing Da Xue Xue Bao 40, 471475.

Niu, C., Yan, H., Yu, T., Sun, H. P., Liu, J. X., Li, X. S., Wu, W., Zhang, F. Q., Chen, Y., Zhou, L., et al. (1999). Studies on treatment of acute promyelocytic leukemia with arsenic trioxide: remission induction, follow-up, and molecular monitoring in 11 newly diagnosed and 47 relapsed acute promyelocytic leukemia patients. Blood 94, 3315-3324.

Raffoux, E., Rousselot, P., Poupon, J., Daniel, M. T., Cassinat, B., Delarue, R., Taksin, A. L., Rea, D., Buzyn, A., Tibi, A., et al. (2003). Combined treatment with arsenic trioxide and all-trans-retinoic acid in patients with relapsed acute promyelocytic leukemia. J Clin Oncol 21, 2326-2334.

Sachs, L. (1978a). Control of normal cell differentiation and the phenotypic reversion of malignancy in myeloid leukaemia. Nature 274, 535-539.

Sachs, L. (1978b). The differentiation of myeloid leukaemia cells: new possibilities for therapy. $\mathrm{Br} \mathrm{J}$ Haematol 40, 509-517.

Sanz, M. A. (2006). Treatment of acute promyelocytic leukemia. Hematology Am Soc Hematol Educ Program, 147-155.

Sanz, M. A., Grimwade, D., Tallman, M. S., Lowenberg, B., Fenaux, P., Estey, E. H., Naoe, T., Lengfelder, E., Buchner, T., Dohner, H., et al. (2009). Management of acute promyelocytic leukemia: recommendations from an expert panel on behalf of the European LeukemiaNet. Blood 113, 1875-1891.

Singh, S. K., Clarke, I. D., Terasaki, M., Bonn, V. E., Hawkins, C., Squire, J., and Dirks, P. B. (2003). Identification of a cancer stem cell in human brain tumors. Cancer Res 63, 5821-5828.

Smalley, M., and Ashworth, A. (2003). Stem cells and breast cancer: A field in transit. Nat Rev Cancer 3, 832-844.

Smith, T. J., Khatcheressian, J., Lyman, G. H., Ozer, H., Armitage, J. O., Balducci, L., Bennett, C. L., Cantor, S. B., Crawford, J., Cross, S. J., et al. (2006). 2006 update of recommendations for the use of white blood cell growth factors: an evidence-based clinical practice guideline. $\mathrm{J}$ Clin Oncol 24, 3187-3205.

Visvader, J. E., and Lindeman, G. J. (2008). Cancer stem cells in solid tumours: accumulating evidence and unresolved questions. Nat Rev Cancer 8, 755-768.

Wang, Z. Y., and Chen, Z. (2008). Acute promyelocytic leukemia: from highly fatal to highly curable. Blood 111, 2505-2515. 
Woodward, W. A., Chen, M. S., Behbod, F., Alfaro, M. P., Buchholz, T. A., and Rosen, J. M. (2007). WNT/beta-catenin mediates radiation resistance of mouse mammary progenitor cells. Proc Natl Acad Sci U S A 104, 618-623. 